\title{
Treading in the footsteps of literary heroes: an autoethnography
}

DOI 10.1515/ejthr-2016-0016

received 12 July, 2015; accepted 15 July, 2015

\begin{abstract}
Literary tourism is an increasingly important market within the field of cultural and heritage tourism. However, it is under-represented in the literature. Still not enough is known about the motivations and experiences of literary tourists. This paper offers an autoethnographic account of a literary tourist trip to Le Café Les Deux Magots, a place associated with the writers and philosophers Jean-Paul Sartre and Simone de Beauvoir. The paper discusses the motivations for becoming a literary pilgrim, and describes the meaning attached to the place visited. It underscores the desire for connection with place and reflects on how this is achieved.
\end{abstract}

Keywords: Literary tourism autoethnography motivation pilgrimage connection.

\section{Introduction}

Literary tourism arises when authors or their literature become so popular that people are drawn to either those locations that the author was associated with or those that were featured within the writings of that particular author (Busby \& Klug, 2001). Literary tourism has grown into a commercially significant phenomenon (Hoppen, Brown and Fyall, 2014) and as a result of this place connected to literature is frequently used to promote destinations (Herbert, 2001; Watson, 2006). Indeed, there are a large number of destinations worldwide with literary connections, ranging from places where a favourite author was born, lived or died in those where books were written or set (Watson, 2006).

\footnotetext{
*Corresponding author: Lorraine Brown, Faculty of Management, Bournemouth University, United Kingdom, Tel: +01202 961889 , E-mail: lbrown@bournemouth.ac.uk
}

There is also a thriving industry for products related to literary places such as postcards, books and memorabilia, which can often be purchased in a literary destination. Watson (2006, p. 5) notes that it has become so 'naturalised as a cultural phenomenon ... that one sees literary sites detailed in guidebooks and marked on the road map, and expects (and feels expected) to visit the museum shop and to buy the soap, the postcard and the bookmark'. Numerous online shops have also appeared, selling souvenirs related to authors and literature, and there are several dedicated websites, such as LiteraryPlaces.com, LiteraryTraveler.com, as well as a vast number of blogs (Hoppen et al., 2014).

Literary tourism is considered a niche, but increasingly important market within the field of cultural and heritage tourism (Hoppen et al., 2014). The demand for cultural holidays increased by 17\% between 1997 and 2007 (Mintel, 2011), with cultural tourism accounting for $40 \%$ of all international tourism in 2007. However, there are no statistical data available on the scale or market size of literary tourism, though Mintel published in September 2011 its first ever report on the phenomenon. It must be noted that literary tourism is important not just for its economic contribution, but also for the opportunity it offers a destination to diversify its product and to attract a tourist whose motivation is to experience something of the culture of the place. That an increasing number of tourists are motivated to travel by a desire to pursue their love of literature can be said to mark a positive social phenomenon.

Furthermore, notwithstanding the growth and potential of the literary tourism market, the topic is under-represented in the academic literature just as it is under-exploited by DMOs (Hoppen et al., 2014). Whilst in the last few decades, important research on literary tourism has emerged (see Squire, 1994, 1996; Herbert, 2001; Busby \& Hambly, 2000; Busby \& Klug, 2001; Busby \& George, 2004; Busby, 2004; Anderson \& Robinson, 2002; Watson, 2006), still not enough is known about the motivations and experiences of literary tourists. Robinson (2002) posed the question as to how a book that can induce and motivate readers into tourists. This paper aims to answer this question by providing an autoethnographic account 
of a literary tourist trip to a place associated with the writers and philosophers Jean-Paul Sartre and Simone de Beauvoir.

Though qualitative research methods have received increasing representation in the tourism literature in recent years, autoethnographies are still relatively rare. Komppula and Gartner (2013) attribute this to suspicion and controversy surrounding the method whilst Noy (2007) describes autoethnography as a subversive method that can often be provocative to the reader. Yet Coghlan and Filo (2013) argue that autoethnography should be included in the multiplicity of scholarly voices in the tourism academic community. Among the autoethnographies that have been published are the study of hunting by Komppula and Gartner (2013), the exploration of meaning within charity sport events and philanthropic adventure travel by Coghlan and Filo (2013) and Noy's (2007) account of a family trip to Eilat.

More use could be made of autoethnography however, which, according to Coghlan and Filo (2013), responds to a call for more personal narratives in tourism research as it can offer unique insights that may not be articulated through other methods. It is also a highly practicable method because the accessible nature of tourism as an activity lends itself to autoethnography. Finally, using autoethnographic studies challenges a field that is still dominated by positivist and postpositivist research (Coghlan and Filo, 2013; Noy, 2007).

\section{Defining literary tourism}

Literary tourism, defined by Squire (1996, p. 119) as tourism associated with 'places celebrated for literary depictions and/or connections with literary figures', falls under the category of heritage tourism (Herbert, 2001). Andersen and Robinson (2002, p. xiii) categorise literary tourism as cultural tourism as 'it involves tourists and visitors, identifying with, discovering, and creating signifiers of cultural values with those people who have become part of the cultural mythologies of places'. Meanwhile, literary tourism can be categorised as heritage tourism (see Squire, 1996 and Herbert, 2001), raising the question: what differentiates cultural and heritage tourism?

The National Trust for Historic Preservation (2011) sees an overlap between the two not entirely dissimilar forms of tourism, the key difference being that heritage tourism is more place-based than cultural tourism. To illustrate, seeing the work of an artist in their home or studio is described as a heritage tourism experience whilst visiting the same work in an exhibition is categorised as a cultural tourism experience. When seeking to locate literary tourism, it seems therefore appropriate to keep both cultural and heritage tourism in mind, as the two types overlap (Hoppen et al., 2014).

Meanwhile Busby and Klug (2001) argue that literary tourism is part of media-related tourism, which they define as tourism involving visits to places celebrated for associations with books, authors, television programmes and films. Additionally, the term creative tourism is suggested by Mintel (2011), to include the creative arts, such as design, architecture, music, film, media, music and literature. In his paper on creative tourism, Richards (2011) includes under this heading music, gastronomic and film tourism but given the growth of literary festivals in particular, which encourage the showcasing of new works, it appears appropriate that literary tourism should be included too.

In 1986, Butler produced a useful typology, identifying four types of literary tourism. These are supported and extended by Busby and Klug (2001) who have added two further types, and Mintel has proposed a further two types. Thus 8 types are now introduced. The first type of literary tourism is described as an homage to a location associated with the life of a writer such as a birthplace, place of residence or a graveside (see Squire, 1996; Herbert, 2001; Andersen \& Robinson, 2002; Watson, 2006). The motivations may vary: for some, a dedicated pilgrimage is made whilst for others, the literary place may be a stopping point (Herbert 2001; Collins-Kreiner 2010).

According to Squire (1994, p. 107) 'the private becomes an object for public scrutiny' (p. 107) when literary places are developed. As Fox and Edwards (2004) point out, even gardens can become literary places to attract tourists acquiring meaning from the people who were inspired by them, including Thomas Hardy and DH Lawrence. According to Laing and Frost (2012, p. 46), authors' work becomes 'better illuminated by experiencing first-hand the physical spaces they knew and drew from.' And as Cicero noted, there is an emotional impact, 'somehow stirred in those places in which the feet of those whom we love and admire have trodden'.

Butler's (1986) second form of literary tourism refers to fiction-related literary tourism, concerned with places of significance within the work of fiction and thus less focused on the author. Just as the film tourist will seek out a place featured in a film or TV programme (Kim et al., 2007; Connell, 2012), the literary tourist will seek places featured in a novel. Indeed, according to Connell (2012), literary tourism is an antecedent of film tourism: both share narratives that appeal to the emotions of the viewer/ 
reader, and induce a desire to travel and to experience the place. Watson (2006) notes that the literary tourist experience is likely to be most powerfully compounded when both the place of composition and that of the fictional setting coincide.

The third form of literary tourism is concerned with the development and marketing of places because of their appeal to literary figures. According to Busby (2004), this is a more specialised form of literary tourism, which nonetheless is widely used by the private and public sector to promote areas in order to gain economic benefits (Busby \& Klug, 2001). The last form as put forward by Butler (1986) applies when an area becomes a tourist destination in its own right based on the popularity of an author. To illustrate, the tourism authorities of Shandong province in China have proposed to build a theme park in Ping'an village (population 800), centring around the old home of the famous author, Mo Yan, a Nobel prize winner for literature (Kaiman, 2012).

The fifth and sixth forms of literary tourism that were introduced by Busby and Klug (2001) are travel writing and film-induced literary tourism. Travel writing can carry an influence on tourism decision-making and can therefore be seen as a vehicle for destination marketing. Meanwhile film-induced literary tourism is based on film-induced tourism, whereby a tourist has read an author's work after having viewed the film based on the work: in fact the book may be secondary to the screen version (Busby, 2004).

Finally, Mintel (2011) puts forward two other forms that literary tourism can take in their recent market research report, namely literary festivals and bookshop tourism. According to Mintel (2011), the emphasis at literary festivals was once on 'serious' literature, but has widened considerably and nowadays includes other related events - usually from the wider field of arts - such as films, TV documentaries, audiobooks etc. Herbert (2001, p. 313) notes that 'literary places are no longer accidents of history, sites of a writer's birth or death; they are also social constructions, created, amplified, and promoted to attract visitors', which can be achieved by the creation of a festival. Anderson and Robinson (2002, p. 9) state that 'we now expect them [authors] to appear in person, to present and explain their work, to allow us to hear the voice and see the person behind the work'.

Mintel (2011) defines bookshop tourists as 'people who, when they travel around local bookshops to seek out titles related to the destination they are visiting (guide books, literary maps, literary tours etc.) or to search for books written by local authors'. Bookshop tourism tends to be the domain of independent, often small book retailers, which might specialise in certain literature genres.
An example is the Shakespeare and Company bookshop in Paris, which specialises in books written in English. Coughlan (2012) describes how, as part of a creative writing course at NYU, the shop is used by tutors for readings and discussions.

According to Nigel Beale, who publishes the website LiteraryTourist.com, the demand for small speciality book shops offering quality literary publications, rare or antiquarian books, is increasing. This indicates the status of books as a collector's item with a 'life well beyond the one they enjoy when they are new in the market' (Andersen \& Robinson, 2002, p. 14). Seaton (1996) notes the important role of book towns in rural tourism, pointing to Hayon-Wye (UK) whose annual festival has become one of the most important in the world. Seaton (1996) states that the town owes its success to the attraction of 'quality tourists...educated people with plenty of money' (p. 380).

Though the typologies presented above are useful for categorising activities and visitor types, a lack of supporting empirical data is observed, and this study helps to address this gap in knowledge.

\section{Methodology}

Autoethnography is defined by Ellis et al. (2011) as an approach to research and writing that seeks to describe and analyse personal experience in order to illuminate elements of the wider culture. The researcher uses aspects of autobiography and ethnography to do and write an autoethnography (ibid). Autoethnographers recognise that stories are complex and meaningful phenomena that help the author and the reader to make sense of experience (Noy, 2007). According to Sparkes (2000, p. 21), autoethnographies 'are highly personalised accounts that draw upon the experience of the author/researcher for the purposes of extending sociological understanding'. Closer to literature than to science, the products of autoethnographic research should be accessible, evocative and grounded in empirical experience, so that the reader can empathise with the experience they read about (Ellis \& Bochner, 2000).

Ellis et al. (2011) observe that people don't generally deliberately undergo an experience in order to be able to write an autoethnography about it; rather they retroactively and selectively write about past experiences that are assembled using hindsight. This can be seen in Noy's (2007) account of a family trip to Eilat, about which he composed a poem and then decided to write up as an autoethnography. It is also the approach adopted by 
Brown and Huang (2014) in their cross-cultural analysis of the Beijing Olympic Green. Similarly, I chose to write an autoethnography because of an experience I had of being a literary tourist in Paris. Upon reflection after my return home, I made the decision to put my experience into words and to try to make sense of it to an academic audience. This decision was informed by my awareness that not much is known about the literary tourist motivation or experience. As such, like most qualitative research, my approach was inductive and idiographic in that data were collected with undue influence from pre-existing theories, and the study starts from the personal, from the self (Holloway \& Brown, 2012).

The process of doing and producing an autoethnography is relatively straightforward: researchers use their experience as the starting point for writing their account. They may make use of diaries or notes that they wrote or of photographs that they took at the time of the experience and they may use documentary materials to stimulate recall. Alternatively, they may attempt to recall the experience in its entirety sometime after the event. In my case, I sat quietly with a notebook a few weeks after my trip to Paris, and wrote a full chronological account of the day I visited St-Germain-des-Prés. I followed this with an autobiographical précis of my attachment to the literary works of Jean-Paul Sartre and Simone de Beauvoir and their meaning for me. I hadn't thought of writing an autoethnography before my visit, but my experience was so powerful and poignant that I started to consider the possibility of using my first-hand experience as a literary tourist to reflect on what had motivated my visit and how it satisfied or confounded my expectations.

Writing skills are important in all qualitative research (Caulley, 2006): tension and interest in outcomes are essential traits for qualitative inquiry (Holloway, 2011). This is particularly important when producing autoethnography, which must be aesthetic, emotionally rich and engaging, and must feature character, scene and plot development (Ellis \& Bochner, 2006). As Noy (2007, p. 143) states, 'autoethnography is unique in that its power lies within its discursive,

written mode. It is a text'. In this respect, the 'rules' applied to narrative research are relevant to autoethnography (see Frank, 1995). In order to stimulate empathy and engagement in the reader, the author must also be prepared to be vulnerable, self-revealing (Noy, 2007; Scarles, 2010).

Needless to say, the use of the first person is called for, and is sanctioned according to Tribe and Honggen (2011) if the method justifies and explains its use. Despite the disconnect between an autoethnographic account being narrated in the third person, there are authors who avoid the use of the first person, or who are pressurised to avoid it (Wolcott, 2011): see for example the autoethnography of volunteer tourism by Barbieri, Santos and Katsube (2012). Bearing in mind the importance of a readable narrative, I spent many hours rereading and refining my story, making sure that it was authentic and honest and that it might resonate with the reader. I elected to use the first person because it facilitates engagement with the reader and allows for a more resonant account.

At this point, my narrative was unsupported by literature; it was not treated analytically. Many autoethnographers opt to produce an account that is without academic underpinning, aiming instead to be evocative and to allow readers to enter into their world (Ellis \& Bochner, 2006). Some academics manage to get such narratives published, though it is acknowledged that this is challenging (Komppula \& Gartner, 2013). As Ellis et al. (2011) state, autoethnographers are often required by social science publishing conventions to analyse their experience, which also serves the purpose of illuminating facets of cultural experience that are not included in the personal account. Indeed, autoethnography in general is underrepresented in the academic literature, including tourism, and is often criticised for being narcissistic and self-absorbed, for being neither art nor science (Sparkes, 2000; Holloway \& Brown, 2012). Ellis et al. (2011) claim however, that autoethnography aims to challenge the view that art and science are at odds with each other: it offers a bridge between the two worlds (Ellis \& Bochner, 2006).

Considering the argument within the methods literature regarding treatment of autoethnographic data, I opted to analyse my story, using a varied literature to interpret and to explain my experience. Perhaps, as Ellis acknowledges, I am too socialised in the norms of the academic community, which expects the dialogue with literature and theory (Ellis \& Bochner, 2006)? Perhaps, as Sparkes (2000) confesses, I felt that integrating theory in the account would ward off charges of self-indulgence? Nevertheless, I made the commitment to avoid or minimise the lack of feeling and distanced theorising that often characterise analytic autoethnography: I aimed to 'protect the integrity of the story' (Ellis \& Bochner, 2006, p. 440), to write an account that managed a 'blend of evocative and analytic prose' (ibid, p. 443). This meant moving backwards and forwards from the emic to the etic, in order to take a more analytic view of the data (Holloway \& Brown, 2012). The decision to produce an analytic autoethnography is quite common in tourism research as reflected in Coghlan's study of charity events, which aimed to produce 'a highly personal account of her own 
experiences, which she attempted to contextualise, in as far as possible, through the published studies on volunteering and tourism' (Coghlan \& Filo, 2013, p. 125).

According to Ellis et al. (2011), the criteria for judging autoethnography are different from those usually applied to qualitative research. As Sparkes (2000) states, new criteria are demanded by the emergence of a new method. Ellis et al. (2011) claim that reliability is established in autoethnography if the reader believes that the narrator could have had the experience they describe, that memory recall has not distorted the experience or that the narrator has not taken artistic licence too far. Validity is similarly achieved if the reader believes that the account is lifelike, coherent and engaging. Indeed, according to Ellis and Bochner (2006), if an account is not evocative and does not stimulate an empathetic response, it cannot call itself autoethnography.

\section{The meaning attached to my literary heroes}

Literary tourists differ in terms of the meaning they derive from the literary works they read, hence Herbert (2001) argues that each visitor has a uniquely individual chemistry with a literary place. Furthermore, all qualitative inquiry requires contextualisation because it focuses on meaning, and meaning emerges through context (Holloway \& Brown, 2012). Thus, it is appropriate that I briefly recount the value that I place on the work of Sartre and de Beauvoir, so that the significance of the place I was to visit becomes clear to the reader.

I had first come across Sartre's work at the age of 18 when I read his first novel, Nausea (1938). I was immediately struck by and identified with the horror and gratuitousness of existence as experienced by the protagonist, Roquentin. The meaninglessness of existence is further developed by Sartre in the first novel in his trilogy Road to Freedom. The Age of Reason (1945) sees its central character, Mathieu, grasp that an individual gives significance to his own life; it is not externally conveyed. Life is inherently meaningless and can only be made meaningful by the individual and the choices $\mathrm{s} / \mathrm{he}$ makes. Choice is a recurring word in existentialist philosophy, as is responsible for the choices an individual makes (Sartre, 1943). The principle of commitment is also important; the engagé individual makes choices that should benefit the wider community in some way (Sartre, 1946; de Beauvoir, 1944).
This was reflected in the life led by Sartre himself who took part in numerous political campaigns and demonstrations, including the Algerian fight for independence, the protests of May 1968, and the setting up of the leftwing newspapers such as L'Humanité and La cause du people (de Beauvoir, 1963). The same could be said for de Beauvoir who complemented her philosophical and political writing with involvement in social causes. Indeed, de Beauvoir was inspirational for women in her championing of women's rights in The Second Sex (1949), and in the independent and emancipated way she lived her life. In her first autobiography (1958), she declared that as a young woman she was determined to preserve 'my love of personal freedom, my curiosity, my determination to be a writer' (p. 340). This was profoundly inspiring to me, an encouragement to try to make my own choices, unbound by social convention.

She was not fazed by Sartre's unwillingness to conform to social norms for relationships: 'he couldn't reconcile himself to having to observe and impose rules; he would never be a family man and he would never marry (p. 341)...Sartre corresponded exactly to the dream companion I had longed for' (p. 345). The personal is political says Hanisch (1970), and this was reflected in the way that de Beauvoir and Sartre lived as a couple: they met in 1929 at the Sorbonne where they both studied philosophy (de Beauvoir, 1958); they agreed neither to marry nor to live together; they had an open relationship (de Beauvoir, 1963). De Beauvoir's judgement of the success of the relationship is clear: 'there has been one undoubted success in my life: my relationship with Sartre' $(1963$, p. 659) ...'it is in itself splendid that we were able to live our lives in harmony for so long' (1981, p. 12). Such an approach to relationships was provocative, challenging and unnerving to me. At the same time, it was something I admired and I can confess that it influenced the way I led my personal life.

What I learned about existentialism from reading their fiction and nonfiction and from reading about their personal approach to living had a profound impact on my own life, as I grew to recognise the importance of trying to live authentically, by taking responsibility for my own choices and being committed to social justice. I don't mean to sound self-aggrandising: this is not to say that I succeed consistently in implementing this philosophy and approach to living, but that existentialism offered and continues to offer me a set of guiding principles. The strong desire I felt to mark the importance to me of these two writers was reserved for them alone. Though others have inspired and educated me, it is perhaps because I 
first came across them when young and uninformed: the impact was marked and lasting.

\section{Making a pilgrimage}

During a month-long trip to Paris in 2013, I made a visit to the cafés in the Latin Quarter that are famous for having been frequented by amongst others the French writers and philosophers, Jean-Paul Sartre and Simone de Beauvoir. Though it wasn't the sole purpose of my trip, it was certainly one of the key attractions: something I had been meaning to do for years, ever since I read about the role played by the cafes in their intellectual, political and social life. I would use the word pilgrimage to describe my visit, as my intention was to honour the two writers and to mark my gratitude for their positive and inspirational impact on my life. I placed a lot of emphasis on the visit, looking forward to the emotional connection the place would bring and the closeness that I would feel for my cherished authors who had spent so much of their time in the place where I too would soon find myself. Whilst I visited other sites with literary associations in Paris such as the bookshop Shakespeare and Company, la maison Victor Hugo and la maison Balzac, it was only the visit to the cafes associated with Sartre and de Beauvoir that provoked strong emotion in me.

My use of the word pilgrimage is apt and finds resonance in the tourism literature as Graburn (2001) also refers to the tourist as a pilgrim who is making a sacred journey and seeks to be close to their sacred object; s/he seeks 'a physical body to enable their senses to connect with objects read' (Robertson \& Radford, 2009, p. 206). The parallel between the tourist and the religious pilgrim is drawn by MacCannell (1976) who states that the pilgrim's desire to be in a place with religious meaning is similar to the attraction of tourists to a place embedded with social, cultural and historical meaning. The notion of the literary pilgrim is also referred to by Herbert (1996, 2001) and Walton (2009) as a dedicated scholar prepared to travel to experience places linked with favourite writers; the pilgrim is well educated and with cultural capital to enjoy literary places (Kim et al., 2007).

Whilst religious pilgrimage may be declining, many authors point to its growing replacement by secular pilgrimage (Watson, 2006; Collins-Kreiner, 2010). As MacCannell (1973) notes, God has been replaced by cultural objects that are meaningful and symbolically loaded for tourists whilst Buchmann et al. (2006) claim that the tourist trip is a spiritual experience. In my case, there was indeed a quasi-spiritual dimension to my visit. As an atheist, the existentialist philosophy popularised by Sartre was the closest I came into my life to a bible, a set of rules, to guide me. If Cohen (1979) is right in arguing that a person's spiritual centre is that which carries meaning, this explains why my trip felt momentous. And yet the parallel with religion which similarly offers believers a set of rules by which to live their life was discomfiting, and I was uncomfortably reminded of this when reading a line in Hofmarcher's (1994) text: 'St Germain has become a sort of cathedral for Sartre. A pagan religion, a pope, devotees, a sect.' (p. 83).

\section{Entering La Place Sartre et de Beauvoir}

When I discovered that the area around the church, St-Germain-des-Prés, in Paris' Latin Quarter featured strongly in the production of the literary works referred to above, as well as being the focus for socialising and intellectual and political debates, I was determined that I would go there one day. Unlike Goldhill (2011), who has no sympathy with literary pilgrimages, for whom the love of books doesn't extend to 'authors and their things', I felt drawn to experience the area once frequented by my two literary heroes.

The St-Germain-des-Prés church was built in AD 558. Next to the church is a square where people can sit and often watch the street entertainment that features particularly in the evening. Across the square is le Café Les Deux Magots and around the corner on the Boulevard St Germain is le Café Flore. Next to the latter is one of the brown metal freestanding posts that are dotted around Paris to denote sites of historic interest. The 'histoire de Paris' sign refers to its famous patrons of the past, including Apollinaire, Breton, Trotsky, Camus, Wilde, Aragon, Ernst, Prevert, Verlaine, Gide, Giradoux, Picasso and Hemingway. Indeed, it observes that the cafés played an important role in the cultural life of Paris well before the arrival of the existentialists.

According to Herbert's (2001) categorisation of the qualities of literary places, the Place St-Germain-desPrés boasts the exceptional quality of its connections with the lives of writers and it has the general quality of being located in an attractive setting. Nonetheless, little is done to exploit the area's significance other than to keep open the doors of its cafés to the public. Indeed, Le Café Flore has no exhibits to mark its literary and other 
cultural heritage than the sign denoting the "histoire de Paris' referred to above. As Fawcett and Cormack (2001) state, literary tourism sites are often developed around the life of an author, however in the case of the two cafés in question, they have a different purpose, that of attracting clients to drink and dine there.

Thus the area is not commercialised or spoiled in any way by those responsible for planning in the Latin Quarter. Indeed, more could be done to capitalise on the literary associations of the area. As Herbert (2001) notes, managers of heritage sites usually decide on a coordinated marketing campaign to attract visitors. Perhaps as a significant cultural tourism destination (Pearce 1998) that consistently tops the list of most visited tourist destinations, Paris does not need to exploit every opportunity for tourism, as one might expect in other destinations.

So great is the association between the area and the existentialists that the square, formerly known as La Place St-Germain-des-Prés, has been renamed La Place Sartre et de Beauvoir, and the following inscription is offered:

\section{Jean-Paul Sartre \\ 1905-1980 \\ Simone de Beauvoir \\ 1908-1986 \\ philosophes et écrivains}

This may not mean as much as one might infer, given the fact that the esteem offered to writers in France is reflected generally in its streets named after authors (Herbert, 1996). The prominence of café life in the production of literature and thought is acknowledged in Hofmarcher's (1994) history of Les Deux Magots: 'Jean-Paul Sartre and Simone de Beauvoir would sit at two little tables next to each other and would write without a break for hours, smoking cigarette after cigarette.' (p. 82)

People are often drawn to the preserved home of dead writers (Herbert, 2001; Andersen \& Robinson, 2002; Watson, 2006) because it allows them to feel the author's presence. Furthermore, Anderson and Robinson (2002) note that a writer's home is probably one of the most powerful tourism resources as it provides tangible connections between the 'created' and the 'creator', which allows visitors to engage in diverse emotional experiences. It also offers a real sense of 'behind the scenes', as it is an intimate and authentic experience to be able to be where the author's pen physically touched the paper (ibid). Not only is the writer's home the place where he or she lived, but the 'creative space' where the writer's works were conceived and realised (Smith, 2003). Moreover, the place that an author chooses to live in, other than a birthplace, can be interpreted as a reflection of his/her interests and desires and of a way to express himself/herself (Smith, 2003).

In my case, the place I was drawn to was a site that was not home, but felt like home to Sartre and de Beauvoir. Both frequented the cafe on a daily basis, using it as an office and a socializing space. At one point Sartre slept in a room above the café and later moved to an apartment less than a minute away on la rue Napoleon where he lived for years, though it puzzlingly bears no plaque. By visiting the physical location that they chose to spend much of their time in, I would be able to appreciate the choices they had made, and to visualise their activities, in other words to get closer to them.

\section{Seeking connection}

Anderson and Robinson (2002) state that literary tourists have emotional associations with literary places and indeed my feelings were running high as I approached the Place; I was excited to be able to sit and stand in the places where my literary heroes had been, to be where works of such value to me had been created, where discussions on politics and philosophy had raged. I was, as Watson $(2006$, p. 3) notes, the literary tourist who savours the opportunity to see where their favourite literary works were created. I may even be able to see or touch objects or memorabilia associated with the authors (see Busby \& Klug, 2001).

I found that Les Deux Magots, once a haunt for bohemians and intellectuals, was now a highly expensive brasserie, a fact that I observed might meet disapproval from some of its celebrated former patrons given that the prices exclude those without money. As Brito (2004) argues, tourism converts literary places into a consumer product, which explains how the café can charge higher prices that it does. Nevertheless, there was a jarring disconnect between what it had been, an inclusive meeting place for leftwing writers and artists, and what it was now, an excluding high priced café. I sat for a while outside the café watching the passers-by as well as those tourists who like me had made if not a pilgrimage (I could not know their inner world) then a decision to visit the area: they could be spotted photographing the sign marking the name of the square. They were thus aware of the cultural significance of Sartre and de Beauvoir. The vast majority of the café's clients, however appeared uninterested in the history of the café; it seemed merely a stopping point in their itinerary. Again, I am minded of the parallel with religion, as I felt like a worshipper in a church such as 
Notre Dame who is interrupted by throngs of tourists uninterested in connection. The experience was cheapened.

I sat for an hour, willing myself to be moved from the location and its historic connections. I let my mind wander to the image of Sartre and de Beauvoir sitting in the café, chatting to friends, writing his novels and discussing philosophical ideas and political positions with other intellectuals. This vibrant life is captured by de Beauvoir (1963) in one of her autobiographical works, The force of circumstances, which captures the political and cultural atmosphere of the times. Like the religious pilgrim, I wanted the experience of being moved by my surroundings; I wanted to be transported; I wanted the ecstasy that I had promised myself, in short I longed for what the literature describes as the sense of awe and reverence that comes from physical interaction with a tourist site (see Herbert, 2001).

However, I remained disappointingly unmoved. The café did not offer me the authentic experience that I craved. As Herbert (2001) notes, authenticity is subjectively experienced, and to me, the café didn't faithfully represent the place I had imagined. Perhaps the crowds of tourists got in the way - did they make me feel less special, less uniquely identified with Sartre and with existentialist ideas? Had I become a cliché? I was not one of the film tourists who desire like religious pilgrims to be part of a community of people who share their reverence and passion (Buchannan et al., 2010). Rather, I seemed to fall more into MacCannell's (1976) description of a tourist as pilgrim as one who desires to be alone with a revered artefact. Certainly, my mood was lowered and my expectations of a moving experience were dashed by the crowds around me.

Perhaps also the contrast between what the café had been and what it had become was alienating: it was not what I had imagined it to be; it was not preserved in the way I had fantasised. Much space is dedicated in the literature: as Collins-Kreiner (2010) observes, all tourists have expectations of the trips they make. Mine was certainly dashed at this point. What is more, I felt conspicuous, foolish, and aware that Sartre and de Beauvoir would perhaps resist lionisation - was I not indulging in the cult of the personality that Marx cautioned against? As a Marxist himself, would Sartre not disapprove of my reverence?

My visit thus far was unsatisfactory and frustrating. I was resigned to disappointment and a sobering acknowledgement that reality is rarely matched by expectations and fantasy. Watson and Saunders (2004) observe that when tourists see places linked to literature, they want the reality of the place to be the same as the reality in their mind. This was clearly true for me, and in this I was let down. Collins-Kreiner (2010) argues that pilgrimage research must emphasise subjectivity rather than an object reality, however in my own case, the two were intertwined, as everything changed when I went into the interior of the café.

There in the preserved art deco interior was a simple but striking display of photographs of the personalities who had frequented the café, including Picasso and Hemingway. Most moving to me was that of de Beauvoir who was captured sitting inside the café at a table, head down, writing. The picture was placed above the exact spot where she was sitting in the photograph. This was the moment I had been longing for, I now realise, perhaps all the more precious because it was unexpected and sat in contrast to my earlier feeling of dejection. I softly gasped in wonderment, feeling what I was hoping and expecting to feel all along. I was overcome and entranced by the understanding that I was standing where great works of literature that carried so much meaning for me had been produced.

As Buchmann et al. (2010) observe in their study of film tourism, the physical element in the tourist experience is crucial, allowing the creation of an embodied physical experience. Indeed, they note that embodied knowledge is a central part of a religious experience, furthering the parallel with the pilgrimage (Barsalou et al. 2005). I can attest to the importance attributed to place as without the physical object that linked me to the past, feelings of connection had eluded me.

Booth $(2004$, p. 2) asks: 'What incites the reader to become the uninvited, posthumous guest, to wish to sit in the author's chair or meditate upon the views out the poet's window?' My answer is clear: I was transported; I could imagine I was in the presence of greatness. I am minded of Scarles' (2010) reference in her paper on visual methods to 'the ultimate failure of words' (p. 918) to do justice to experience, as, aware of the religious vocabulary I am using, I can find no other that approximates my emotional response. I am also aware but little caring that I am contradicting at this point the clear-sighted perspective, I had adopted earlier when I tried to rationalise my unexpected struggle to feel a connection with the place. Tourists are 'agents of multiple and even contradictory interpretations of sites', according to Fawcett and Cormack (2001, p. 700). I clearly wanted to be moved; I wanted the ecstasy of the pilgrim visiting a sacred site, and I wanted this above an intellectual analysis of the disconnect between what the café represented in the past and what it had become. I left the café and the area satisfied with the feelings they had provoked in me. I experienced a renewed awareness 
of and attachment to the profound influence Sartre and de Beauvoir had and continue to have on my life. Like the pilgrim, my faith was strengthened. Such was the intensity of my experience that I returned to the café a number of times during my stay, making sure to sit inside and in the same spot, drawn by the desire to experience both the stillness and the awe that the place provoked in me.

\section{Conclusion}

This paper has located literary tourism within the wider field of cultural and heritage tourism, and has provided definitions and typologies to permit a grasp of this growing phenomenon. Using an autoethnographic method, this paper documents the experiences and motivations of one literary tourist that falls into the first category of Butler's (1986) typology, in that it describes homage to a location associated with the life of a writer. This autoethnography offers an account of an emotional attachment to two writers and of a consequent decision to make a pilgrimage to a place associated with them. It reveals the emotional responses to the site, charting both the disappointments and the euphoria it provoked. As Noy (2007) states, autoethnography is able like few other methods to illustrate the emotional complexities and contradictions in the travel experience of tourists, to show how much of tourism experience involves feelings of sadness and alienation that are often not easy to acknowledge

The role of the physical space in the tourist experience was highlighted in this paper. There was a clear link between a desired feeling of awe and reverence in response to being in the place where great works of literature were produced and the perception of authenticity. Mere presence in a place with historical associations, but with no attempt at preservation of some historical features would be insufficient to engender feelings of wonder that the literary pilgrim is seeking.

Literary tourism is a growing phenomenon and there is evidence that some DMOs have developed their product around their destination's literary heritage, but is acknowledged that more could be done to capitalise on literary associations and to thereby attract more tourists and to tap into a different market segment (Hoppen et al. 2014). Further research can help to foster awareness of what the literary tourist wants from their trip, what motivates and satisfies them.

This paper provides some called for understanding of the motivations and experiences of one type of literary tourist. This understanding could be broadened by widening the sample to allow for the capturing of a more diverse experience. Future research could be conducted retrospectively or in situ, at sites of interest to literary tourists: qualitative data could be collected using observational and interview methods. The researchers could also focus on the other categories of literary tourism developed by Butler and colleagues in order to further determine how a destination can respond to the needs of literary tourists.

\section{References}

[1] Andersen, H.-C. \& Robinson, M. (2002). Literature and tourism: Reading and writing tourism texts. London: Continuum

[2] Barbieri, C., Santos, C and Katsube, Y. (2012) Volunteer tourism: on the ground observations from Rwanda. Tourism Management, 33, pp. 509-516

[3] Barsalou, L. W., Barbey, A. K., Simmons, W. K., \& Santos, A. (2005). Embodiment in Religious Knowledge. Journal of Cognition and Culture, 5(1-2), pp. 14-57

[4] Bochner, A. (2001) Narrative's virtues. Qualitative Inquiry, 6(2), pp. 266-272

[5] Booth, A. (2004). Homes and haunts and the real right place of Henry James. In M. Robinson, \& D. Picard (Eds.), Conference Proceedings Tourism and Literature: Travel, Imagination and Myth, 22-26 July 2004, Harrogate. Sheffield: Centre for Tourism and Cultural Change

[6] Brito, L. M. (2004). Tourism promotion and literary itineraries. In M. Robinson, \& D. Picard (Eds.), Conference Proceedings Tourism and Literature: Travel, Imagination and Myth, 22-26 July 2004, Harrogate. Sheffield: Centre for Tourism and Cultural Change

[7] Brown, G. \& Huang, S. (2014) Interpreting Tourism at Olympic Sites: A Cross-cultural Analysis of the Beijing Olympic Green. International Journal of Tourism Research DOI: 10.1002/jtr.1994

[8] Buchmann, A., Moore, K \& Fisher, D. (2010) Experiencing film tourism: authenticity and fellowship. Annals of Tourism Research, 37(1), pp. 229-248

[9] Busby, G. (2004). Representations of Cornwall in fiction: the influence on tourism. In Robinson, M. \& Picard, D. (Eds.), Conference Proceedings Tourism and Literature: Travel, Imagination and Myth, 22-26 July 2004, Harrogate. Sheffield: Centre for Tourism and Cultural Change

[10] Busby, G. \& George, J. (2004).The tailor of Gloucester: Potter meets Potter - Literary tourism in a Cathedral City. In M. Robinson \& D. Picard (Eds.), Conference Proceedings Tourism and Literature: Travel, Imagination and Myth, 22-26 July 2004, Harrogate. Sheffield: Centre for Tourism and Cultural Change

[11] Busby, G. \& Hambly, Z. (2000). Literary tourism and the Daphne du Maurier Festival. In P. Payton (Ed.), Cornish Studies 8. Exeter: University of Exeter Press, pp. 197-212. Available from: http://plymouth.academia.edu/GrahamBusby/Papers/10090/ Literary_Tourism_and_the_Daphne_du_Maurier_Festival

[12] Busby, G., \& Klug, J. (2001). Movie-induced tourism: The challenge of measurement and other issues. Journal of Vacation Marketing, 7(4), pp. 316-332 
[13] Butler, R. (1986). Literature as an influence in shaping the image of tourist destinations: A review and case study. In J. Marsh (Ed.), Canadian studies of parks, recreation and foreign lands. Trent University, pp. 111-132

[14] Caulley, D. (2008) Making qualitative research reports less boring: the techniques of writing creative nonfiction. Qualitative Inquiry, 14, pp. 424-449

[15] Coghlan, A. \& Filo, K. (2013) Using constant comparison method and qualitative data to understand participants' experiences at the nexus of tourism, sport and charity events. Tourism Management, 35, pp. 122-1311

[16] Cohen, E. (1979). A phenomenology of tourist experience. Sociology, 13, pp. 179-201

[17] Collins-Kreiner, N. (2010). Researching pilgrimage: Continuity and transformations. Annals of Tourism Research, 37, pp. 440-456

[18] Connell, J. (2012) Film tourism - evolution, progress and prospects. Tourism Management, 33, pp. 1007-1029

[19] De Beauvoir, S. (1944) Pyrrhus et Cinéas. Paris: Gallimard

[20] De Beauvoir, S. (1958) Mémoires d'une jeune fille rangée. Paris: Gallimard

[21] De Beauvoir, S. (1963) La force des choses. Paris: Gallimard

[22] De Beauvoir, S. (1981) Le Ceremonie des adieux. Paris: Gallimard

[23] Ellis, C. (2007) Telling secrets, revealing lives: Relational ethics in research with intimate others. Qualitative Inquiry, 13(1), pp. 3-29

[24] Ellis, C. \& Bochner, A. (2000) Autoethnography, personal narrative, reflexivity. In N. Denzin, \& Y. Lincoln (Eds). Handbook of qualitative research (2nd ed), pp. 733-768 Thousand Oaks, CA: Sage

[25] Ellis, C \& Bochner, A. (2006) Analyzing analytic autoethnography. An autopsy Journal of Contemporary Ethnography, 35(4), pp. 429-449

[26] Ellis, C., Tony, E. \& Bochner, A. ( (2011) Autoethnogrpahy: an overview. Forum Qualitative Social Research, 12(1), Art 10 Available from: http: //nbn-resolving.de/urn:de:0114fqs1101108

[27] Fawcett, C. \& Cormack, P. (2001) Guarding authenticity at literary tourism sites. Annals of Tourism Research, 28(3), pp. 686-704

[28] Fox, D \& Edwards, J. (2004) The role of cognitions in the leisure and tourism motivation process, with reference to gardens. Tourism and literature: travel, imagination \& myth. Harrogate, 22-26 July 2004

[29] Frank, A. (1995) The wounded storyteller. Chicago: CUP

[30] Goldhill, S. (2011) Freud's couch, Scott's buttocks, Bronte's grave. University of Chicago Press

[31] Graburn, N. (2001). Secular ritual: A general theory of tourism. In V. Smith (Ed.), Hosts and guests: Tourism issues of the 21st century, pp. 42-50. Elmsford: Cognizant Communications

[32] Hanisch, C. (1970) The Personal Is Political. Notes from the Second Year: Women's LLiberation. S. Firestone \& A. Koedt (Eds) Available from: http://www.carolhanisch.org/CHwritings/ PIP.html Accessed on 3/12/2012

[33] Herbert, D. (1996) Artistic and literary places in France as tourist attractions. Tourism Management, 17(2), pp. 77-85

[34] Herbert, D. (2001) Literary places, tourism and the heritage experience Annals of Tourism Research, 28(2), pp. 312-333
[35] Hofmarcher, A. (1994) Les Deux Magots: chronique d'un café litteraire. Paris: Le Cherche-Midi

[36] Holloway, I. (2011) Being a qualitative researcher. Qualitative Health Research, pp. 968-975

[37] Holloway, I. \& Brown, L. (2012) Essentials of a qualitative doctorate. Walnut Creek, CA: Left Coast Press

[38] Hoppen, A, Brown, L. \& Fyall, A. (2014) Literary Tourism: Opportunities and Challenges for the Marketing and Branding of Destinations? Journal of Destination Marketing \& Management, in press

[39] Kaiman, J. (2012) Theme park plan for humble home of Mo Yan. The Guardian, 24 October, p. 22

[40] Kim, H., Cheng, C. \& O’Leary, J. (2006) Understanding participation patterns and trends in tourism cultural attractions, Tourism Management, 28, pp. 1366-1371

[41] Kim, S., Agrusa, J., Lee, H. \& Chon, K. (2007) Effects of Korean television dramas on the flow of Japanese tourists. Tourism Management, 28, pp. 1340-1353

[42] Komppula, R. \& Gartner, W. (2013) Hunting as a travel experience: An auto-ethnographic study of hunting tourism in Finland and the USA. Tourism Management, 35, pp. 168-180

[43] Laing, J. and Frost, W. (2012) Inspiration, Quests and Transformation Bristol: Channel View Publications

[44] MacCannell, D. (1976). The Tourist: A New Theory of the Leisure Class. New York: Schocken Books

[45] Mintel (2011). Literary tourism - international - September 2011. London: Mintel

[46] Noy, C. (2007). The Poetics of Tourist Experience: An Autoethnography of a Family Trip to Eilat. Journal of Tourism and Cultural Change, 5(3), pp. 141-157

[47] Richards, G. (2011) Creativity and tourism: state of the art. Annals of Tourism Research, 38(4), pp. 1225-1253

[48] Robertson, J. P. \& Radford, L. A. (2009). The private uses of quiet grandeur: A meditation on literary pilgrimage. Changing English, 16(2), pp. 203-209

[49] Robinson, M. (2002). Between and beyond the page: Literature - tourism relationships. In H-C. Andersen \& M. Robinson (Eds), Literature and tourism - Reading and Writing Tourism Texts. London: Continuum

[50] Sartre, J.-P. (1938). La Nausee (Nausea). Paris: Gallimard

[51] Sartre, J.-P. (1943). L'etre et le neant. Paris: Gallimard

[52] Sartre, J.-P. (1945) L'age de raison. Paris: Gallimard

[53] Scarles, C. (2010) Where words fail, visuals ignite: opportunities for visual autoethnography in tourism research. Annals of tourism research, 37(4), pp. 905-926

[54] Seaton, A.V. (1996) Hay one Wye, the mouse that roared: book towns and rural tourism, Tourism Management, 17(5), pp. 379-385

[55] Smith, A. K. (2003) Literary enthusiasts as visitors and volunteers. International Journal of Tourism Research, 5(2), pp. 83-95

[56] Sparkes, A.C. (2000) Autoethnography and narratives of self: reflections on criteria in action, Sociology of Sports Journal, 17, pp. 21-43

[57] Squire, S. J. (1994). The cultural values of literary tourism. Annals of Tourism Research, 21, pp. 103-120

[58] Squire, S. J. (1996). Literary tourism and sustainable tourism: Promoting 'Anne of Green Gables' in Prince Edward Island. Journal of Sustainable Tourism, 4(3), pp. 119-134 
[59] Tribe, J. \& Honggen, X. (2011) Editorial: developments in tourism social science. Annals of Tourism Research, 38(1), pp. 7-26

[60] Walton, J. (2009) Prospects in tourism history: Evolution, state of play, and future developments. Tourism Management, 30, pp. 783-793

[61] Watson, N. J. (2006). The literary tourist. Basingstoke: Palgrave Macmillan.

[62] Watson, C. \& Saunders, R. (2004). The production of literary landscapes. In M. Robinson \& D. Picard (Eds.), Conference Proceedings Tourism and Literature: Travel, Imagination and Myth, 22-26 July 2004, Harrogate. Sheffield: Centre for Tourism and Cultural Change
Lorraine Brown teaches qualitative research methods to Masters and doctoral students and she teaches French to tourism undergraduates. Her research interests include international education, identity and travel, literary tourism and culture contact. She has published two textbooks on qualitative research methods, one for doctoral students and the other for undergraduates. 